\title{
Unpacking the Strength of the State: The Utility of State Infrastructural Power
}

\author{
Hillel Soifer • Matthias vom Hau
}

(C) Springer Science + Business Media, LLC 2008

Keywords Infrastructural power - State strength - State capacity

States are central to development and human well-being. ${ }^{1}$ In Afghanistan, Haiti, and the Democratic Republic of Congo, which for many contemporary commentators epitomize weak or fragile states, the inability to provide security and establish a presence throughout their territory has left local communities vulnerable to warlords and militias and undermined the prospect of economic growth and basic social provision. Other states, for instance Nicaragua, Nigeria, and Peru, have been better able to bring an end to enduring cycles of civil violence and warfare. Yet the provision of basic security and public goods remains fragmented and confined to certain territorial areas, leaving out substantial parts of the population. ${ }^{2}$ Unlike these countries, a wide range of others, including Costa Rica and the Indian state of Kerala, while by no means endowed with a strong state by any conventional means,

\footnotetext{
${ }^{1}$ Some of the examples in this paragraph draw on the work of the Crisis States Research Centre (2005).

${ }^{2}$ In Peru the inability of the state to provide for its citizens is reflected in the failed 2005 census, which had to be repeated in October 2007, and required a national restriction on daily activity for its implementation. See news.yahoo.com/s/nm/20071021/wl_nm//Peru_census_dc.
}

The order of authorship is alphabetical. The two editors contributed equally to this introductory essay. Thanks to Fulya Apaydin, Dan Slater, Daniel Ziblatt, and the two reviewers for helpful comments and suggestions.

H. Soifer $(\bowtie)$

Department of Politics, Princeton University, 039 Corwin Hall, Princeton, NJ 08544, USA

e-mail: hsoifer@princeton.edu

M. vom Hau

Brooks World Poverty Institute, The University of Manchester,

Humanities Bridgeford Street Building, Oxford Road, Manchester M13 9PL, UK

e-mail: Matthias.vomHau@manchester.ac.uk 
have even managed to achieve certain levels of economic and social well-being. To better understand what enables some states to secure peace and promote economic growth, welfare, and democracy, it is necessary to sharpen our understanding of what we mean by weak and strong states by unpacking the much-abused concepts of state strength and weakness.

When scholars wrestle with state strength, they usually resort to assessing state capacity, which is broadly a function of state bureaucracy, the state's relations with social actors, and its spatial and societal reach. High capacity states are seen as generally better equipped to establish a monopoly of violence, enforce contracts, control their populace, regulate institutions, extract resources, and provide public goods. Analysts view state capacity as crucial to explain outcomes as diverse as economic growth and development (e.g., Coatsworth 1998; North 1981), democratization and democratic stability (e.g., Linz and Stepan 1996; O'Donnell 1993), citizenship regimes (e.g., Yashar 2005), social welfare provision (e.g., Skocpol 1992; Steinmetz 1993), as well as identity politics and political culture (e.g., Berezin 1997; Kertzer and Arel 2001). Likewise, state capacity has been identified as critical for explaining variations in state surveillance (e.g., Torpey 2000), nationalism (e.g., Gellner 1983), civil violence (e.g., Fearon and Laitin 2003; Goodwin 2001), the intensity of international wars (e.g., Centeno 2002), and state-sponsored violence against their own populace (e.g., Straus 2006; Rogers 2006).

Yet scholarly attention to the different dimensions of state capacity has been uneven. Two broad and well-developed research programs trace variations of state capacity to the relative autonomy of the state from societal actors (e.g., Bates 1981; Evans 1995; Marx 1978; Nordlinger 1981; Skocpol 1979; Waldner 1999) and the professionalization (or "Weberianess") of its bureaucracy (e.g., Carpenter 2001; Evans and Rauch 1999; Geddes 1994; Skowronek 1982; Weber 1968). Beyond these systematic research programs, scholars explore the manifold impacts of a third dimension, often called state reach or power. To give but two examples, Jeffrey Herbst (2000, 173) explores "the inability of African states to project power over distance." Theda Skocpol's (1979) classic study of the origins of social revolution argues that the "weakening grip of the civil administration over the country" (p. 74) contributes to the fiscal crisis of the old regime and plays a fundamental role in its collapse.

A closer examination of these studies - as well as many others-reveals a common object of study. By state reach, power, and the like, these scholars are in fact exploring what Michael Mann has called the infrastructural power of the state: its institutional capability to exercise control and implement policy choices within the territory it claims to govern. The ability of the state to exercise control and implement policies varies widely: states that are weaker in this regard are unable to assess and collect taxes, or even effectively carry out a national census. ${ }^{3}$ Despite Mann's development of the concept of infrastructural power more than two decades ago, ${ }^{4}$ social scientists have not developed the body of empirical and conceptual knowledge around it, which has characterized the research programs based on the

\footnotetext{
${ }^{3}$ Centeno (2002) uses the national census as a proxy for the infrastructural power of the state.

${ }^{4}$ Mann (1984) first developed the idea of infrastructural power in his 1984 essay, and further elaborated on it in his two-volume history of social power $(1986,1993)$.
} 
autonomy and bureaucracy of the state. ${ }^{5}$ The goal of this collection of articles is to provide a roadmap for filling that void, demonstrating the utility of the conceptual framework of infrastructural power for precisely assessing the reach or power of the state, and for developing explanations of its origins and effects.

While few scholars have engaged explicitly with Mann's concept, many have explored precisely these aspects of the state and its relations with societal actors under other terminology. For example, Lawrence Boudon (1996: 288) defines the Colombian state's weakness as its inability "to establish its legal authority and legitimacy throughout the entire national territory." Deborah Yashar (2005: 6) defines the "reach" of the state as its "actual penetration throughout the country and its capacity to govern society," which also fits very closely with Mann's concept of infrastructural power. The heterogeneity of terminology has contributed to some imprecision about the meaning of state strength or state power, but reexamining this body of research with Mann's concept in mind creates greater conceptual clarity and generates significant payoffs for knowledge accumulation. In other words, a wide variety of scholars would benefit from drawing explicit connections between their analyses and Mann's framework of infrastructural power.

Many scholars of democracy are concerned with the strength or evenness of the state. Juan Linz and Alfred Stepan (1996: 11) write, "modern democracy ... needs the effective capacity to command, regulate, and extract." Democracy cannot be consolidated where the state cannot reach through society to enforce its policies. Guillermo O'Donnell (1993) more explicitly explores the territorial aspect of state strength in his discussion of "brown areas" and the limitations of democracy. A similar focus on the ability of the state to implement policy throughout its territory has long characterized the study of insurgency and revolution. A weak statelacking those implementation capabilities - determines the presence and persistence of domestic conflict (Fearon and Laitin 2003) and is a necessary condition for social revolutions to occur (Goodwin 2001; Skocpol 1979). Scholars also highlight the presence of the state when explaining its role in influencing ideology and culture (Wuthnow 1989), as well as defining subjects and social identities (Wimmer 2002). A state whose coercive and regulatory institutions do not reach through society is unlikely to develop the symbolic power of being seen as an almost natural force in shaping the daily lives of its populace (Loveman 2005). Thus, scholars of many aspects of politics and state-society relations explore precisely those aspects of the state captured in Mann's concept of infrastructural power.

The focus of many economic historians on the effectiveness of property rights and on the public goods provided by the state reveals the importance of Mann's concept in that field. For example, John Coatsworth's (1998) investigation of the roots of economic stagnation in nineteenth-century Latin America argues that the provision of security, infrastructure, and other basic functions by states is a fundamental requirement for economic growth. Analogously, the ability of the state to enforce laws-particularly the laws governing property rights - is central to Douglass

\footnotetext{
${ }^{5}$ Some scholars have fruitfully employed Mann's concept. See for example Ziblatt (2006), who shows that levels of subnational infrastructural power explain the divergent state structures of Germany and Italy, and Weiss (2006), who shows that increased levels of infrastructural power help to explain economic development in North East Asia.
} 
North's (1981) account of economic development. As such, economic historians are centrally concerned with the ability of the state to penetrate society and implement its chosen policies.

In studying this aspect of the state, Mann's conceptual framework has two significant advantages in that it highlights the spatial dimension of the state and the relational nature of its power. The ability of states to carry out their projects is territorially organized and crucially shaped by the organizational networks that they coordinate, control, and construct. Thus, examining state infrastructural power draws attention to subnational territorial variation in the ability of the state to exercise control and regulate society, and draws scholars to subnational comparison in addition to cross-national research (see Snyder 2001). For example, the territorial variation in the power of the state underlies the emergence and persistence of the Colombian insurgency. ${ }^{6}$ The Revolutionary Armed Forces of Colombia (FARC) and the National Liberation Army (ELN) confront a state that has not built significant infrastructure in the rural regions of the country, but that remains quite effective in the major cities - and particularly in the capital of Bogotá. Similarly, cities can also be places where state infrastructural power is severely limited. In Nicaragua's capital city of Managua, security and social provision are confined to territorial pockets inhabited by elite sectors of the population, whereas in most of the city state power is eclipsed by social monopolies of violence exercised by gangs and drug syndicates (Rogers 2006).

The spatial unevenness of the state's capacity in Colombia and Nicaragua can best be understood with reference to Mann's conceptual framework. A focus on the effects of uneven state infrastructural power directs scholars to subnational investigation of the dynamics of the state at the local and regional level. A subnational approach to the state's ability to exercise control and regulate social relations is also a central feature of several of the articles in the present collection, in particular Daniel Ziblatt's study on public good provision in nineteenth-century German cities and Daniel Schensul's analysis of urban development in postApartheid Durban.

Second, Mann's concept emphasizes the relational nature of state capacity. Infrastructural power not only radiates from the administrative activities of states, it is also grounded in the organizational entwining (Gorski 2003) between state and nonstate actors. For instance, when analyzing the power of local state actors, the power of the Manchester (England) City Council to initiate and coordinate the urban regeneration of this old industrial city was significantly enhanced by private support through institutionalized connections between city authorities and local economic elites (Kidd 2006). Moreover, state infrastructural power is shaped by the relationships among different state agencies themselves. For example, it is not clear whether educational bureaucrats and public school teachers in Venezuela will actually submit to the recent school curriculum changes ordered by President Hugo Chávez. The relational nature of infrastructural power allows analysts to move past debates that juxtapose state and society as opponents to examine the varied forms of their interaction. In this collection of articles, Matthias vom Hau's essay on nationalism in Mexico and Argentina develops this point more explicitly.

\footnotetext{
${ }^{6}$ Among many scholars making this argument is Kline (1999).
} 


\section{Drawing Conceptual Boundaries}

The spatial and relational focus of the concept also helps to demonstrate the central place of state infrastructural power in a variety of research areas without engaging in the sort of conceptual stretching criticized by Giovanni Sartori (1970), David Collier and Steven Levitsky (1997), and Gary Goertz (2005). Instead, as the articles in this issue show, it is important to distinguish carefully between this aspect of state capacity and others. In particular, state infrastructural power must be distinguished from the well-developed concepts of state bureaucracy and state autonomy, and from Mann's concept of despotic power.

Mann's conception of the state draws both on Karl Marx and on Max Weber, and his conception of infrastructural power falls more in the Weberian tradition of statist analysis. ${ }^{7}$ The state's despotic power refers to the range of policies that it can order: in Mann's analogy from Alice in Wonderland, the despotic power of the Red Queen refers to her ability to order one's head to be cut off. The extent of the state's freedom from societal constraints on policy choice is shaped largely by its autonomy from societal actors, or the extent to which state leaders can enact their own preferences into policy. Infrastructural power, which captures the ability of the Red Queen to hunt down Alice and enforce her decapitation, is related to the extent that the bureaucracy carries out the policies chosen by state elites. Mann's two-fold distinction between infrastructural and despotic power mirrors the distinction between the bureaucratic capacity of the state and its autonomy.

At the same time, as shown above and in the articles in this issue, infrastructural power is distinct from the bureaucratic professionalism of the state. ${ }^{8}$ While state infrastructural power focuses on the ability of the state to control and regulate social relations throughout the territory it claims to govern, Weberianess focuses on the nature of the bureaucracy. There is a relationship between the training and expertise of the bureaucracy, and the ability of the state to enforce policies, since policy is frequently enforced by state agents. Yet, as Ziblatt shows in his contribution to this collection, we can differentiate between the professionalism of the state bureaucracy and the state's power by distinguishing between the capacity of higher level bureaucrats designing policy and of the lower rungs of the civil service hierarchy who implement it. While the characteristics of the higher rungs capture bureaucratic professionalism, the characteristics of the lower ranking members provide information about the implementation ability of the state.

Although infrastructural power is distinct from both autonomy and bureaucracy of the state, its relationship to these other aspects of state capacity is more than simply additive. The essays assembled in this issue suggest some initial steps toward unpacking the causal relationships between these distinct dimensions, pointing to avenues for further research. As it stands, the causal impact of bureaucracy on state infrastructural power remains uncertain. Schensul's article identifies the Weberianess

\footnotetext{
${ }^{7}$ The relationship between Mann's framework and Weber's analysis of the state is developed further in Soifer's essay in this issue.

${ }^{8}$ In other words, there is a distinction between bureaucratic professionalism and state capacity: the latter encompasses the former as well as the infrastructural power of the state.
} 
of Durban's bureaucracy as a necessary condition for the state's ability to transform the city's spatial hierarchy. Ziblatt also suggests that bureaucratic professionalism (in his case, at the local level in a federal system) has the potential to generate infrastructural power. Thus, bureaucratic professionalism is one potential factor among many possible causes of state infrastructural power. Conversely, the causal influence of state infrastructural power on bureaucratic professionalism is arguably more direct. Infrastructural power is crucial for the Weberian performance of state apparatus. As Soifer argues, the inability of the state to penetrate civil society through routine communication and regulatory means undermines the construction of an efficient state bureaucracy. Infrastructural power is perhaps a necessary condition for bureaucratic effectiveness.

The causal relationships between infrastructural power and state autonomy again remain underspecified. As Soifer argues when tracing Mann's genealogy of the concept, the genesis of infrastructural power presupposes a certain degree of autonomy of the state apparatus from civil society. Without autonomy from societal actors, the state cannot be seen to control society and regulate social relations across its territories. At the same time, the expansion or reproduction of infrastructural power is not necessarily dependent on state autonomy. As many of the advanced industrial countries illustrate, infrastructurally powerful states are often characterized by limited state autonomy. It is precisely the organizational entwining between state agencies and civil society organizations that is often constitutive of infrastructural power. ${ }^{9}$ One possible avenue for further exploration of this causal relationship is to identify different kinds of state autonomy and their differential effects on infrastructural power. ${ }^{10}$ Slater's essay indicates that under certain conditions mass mobilizing parties engender the expansion of public services, whereas the lack of autonomy from local elites reduces such an ability for basic provision. A close entwining of representative institutions with the state apparatus may engender infrastructural power, while a similar entwining of the state apparatus with specific elite sectors may work the opposite way.

The contributions assembled here also point to the complex relationship between infrastructural power and violence. Many analyses of the state-including Mann'sbegin from the Weberian conception of the state as the monopoly of legitimate violence. This conceptual starting point poses two distinct analytical puzzles. First is the question of whether the use of violence in the domestic context by state forces reflects infrastructural power. Second are the conclusions to be drawn about the state's infrastructural power from violence by nonstate actors.

State violence is one way used to exercise control over society and implement policies. Resorting to coercion reflects a state that lacks the necessary organizational entwining with civil society to meet its goals. As such, a high level of state violence does not imply an infrastructurally powerful state. Yet state violence is not necessarily a sign of an infrastructurally weak state. Even infrastructurally strong states may resort to force under some circumstances. We can see this, for example, in

\footnotetext{
${ }^{9}$ Schensul suggests in his essay that infrastructural power can instead act in the absence of organizational entwining (embeddedness or synergy) to allow states to effectively implement policy.

${ }^{10}$ We are grateful to Miguel Angel Centeno for this idea.
} 
the repression exercised by the Pinochet government in Chile after it came to power in 1973. Although it does not shape the level of violence, infrastructural power may shape the forms of violence employed by the state. Kalyvas (2006), as discussed in more detail in Soifer's essay, has argued that infrastructural power influences the selectivity of state violence. A comparison of the violence inflicted by Latin America's military governments of the 1970s against civil society actors shows that the Chilean state was more selective and effective in its repression than its counterpart in Argentina, where a much higher level of violence was less effective in silencing opposition. The Weberian conception of the state highlights the fact that infrastructurally strong states have a unique claim to the legitimate violence, yet it does not shed light on the level of violence that they exercise.

In turn, violence exercised by nonstate actors may be also be shaped by the state's infrastructural power. As Matthew Lange and Hrag Balian show in their article, there are two countervailing views of the relationship between state power and civil violence. On the one hand, civil violence may characterize infrastructurally weak states, which lack the power to contain it. Another logic holds that the state's capability to control and regulate social relations - its infrastructural power-is precisely the trigger instigating violence by societal actors. These competing mechanisms complicate the relationship between infrastructural power and the various forms of civil violence. As with state violence, violence by nonstate actors sheds no clear light on the infrastructural power of the state, but points to the need for context-specific analyses of the relationship between infrastructural power and violence.

\section{Advancing the Study of State Infrastructural Power}

The contributions of this special issue are not just a demonstration of the usefulness of Mann's concept across a variety of substantive areas. By unpacking state infrastructural power and drawing its conceptual boundaries, the articles assembled here also raise broader issues that speak to central puzzles and debates in the study of the state.

First, the articles' focus on the precise conceptualization and measurement of state infrastructural power has major ramifications for the study of democracy. Many works in the political regime literature define and operationalize democracy by including the effectiveness of government as a key conceptual dimension (e.g., Huntington 1968; Inglehart and Welzel 2005; Putnam et al. 1993). Yet, as illustrated in Ziblatt's essay on the varying effectiveness of German city governments to provide public healthcare facilities, the capacity to actually implement political decisions is an attribute of political authority, and not a regime quality. Drawing a clear distinction between state infrastructural power and government accountability helps researchers to disentangle the complex causal relationship between regime type and state infrastructural power, and suggests the analytical utility of a more minimal definition of democracy.

For example, works by James Holston and Teresa Caldeira (1998) on disjunctive democracy in Brazil or Steven Levitsky and Maria Victoria Murillo (2006) on the institutional weakness of democracy in Argentina have shown that the state's ability to exercise effective control and implement policy may strengthen democracy, while 
the lack of infrastructural power is likely to create obstacles to the stability and inclusiveness of democratic institutions. In this special issue, Dan Slater's essay suggests that the causal arrow can be reversed, and that regime factors can influence the development of state infrastructural power. His comparative study of democratization in Southeast Asia shows that competitive high-stakes national elections in a context of robust mass political mobilization can lead to an increase in the power of the state. Distinguishing carefully between regimes and states allows scholars to explore the relationship between them, and Mann's conceptual approach to statesociety relations provides a particularly apt framework for this purpose.

By putting the concept of infrastructural power to work, this special issue also allows us to highlight two concepts that Mann's framework fails to sufficiently distinguish: spatial and social control. In his original definition, Mann emphasized the inherently territorial nature of state infrastructural power, focusing on the capacity of state institutions to radiate outwards from the center and exercise control. As such, Mann ultimately does not clarify whether he refers to control over territory or control over social relations. Yet, as Schensul's article shows, the distinction between the spatial and the social is crucial. Even the presence of "logistical techniques" such as schools or police officers in the most remote areas may not guarantee control over society. Schensul's study of post-apartheid Durban argues that the preexisting public infrastructure in fact undermined the capacity of the city government to foster racial integration, whereas previously stateless territories were those most easily transformed. If we follow Mann's (1986) approach and think of society as constituted of multiple, overlapping social networks (pp. 1-3, 13-17), social control needs to be treated as analytically distinct from spatial control. As recent examples from the immigration and the nationalism literatures illustrate, states may employ infrastructural power to exercise control over national minorities situated outside their territorial boundaries (Brubaker 1996; Fitzgerald 2008). The actual exercise of state infrastructural power may not only vary across territory, but also across social categories of membership and exclusion, such as the distinctions between citizens and foreigners, men and women, or fully included "nationals" and racial minorities (Marshall 1963; Winant 2001; Wimmer 2002). ${ }^{11}$

Similarly, spatial and social control do not automatically translate into the state's ability to implement policy, highlighting a tension within Mann's very definition of state infrastructural power. Vom Hau's study of state infrastructural power and nationalism shows that even though in mid-twentieth-century Argentina the state marshalled comparatively higher levels of state infrastructural power than the Mexican state during the same period, the former did not manage to institutionalize a new national ideology as a hegemonic frame of reference. The improved technologies of control, such as tax revenues, schools, police officers, and roads available to the Argentinean state, did not translate into an enhanced capability to implement its goals. Thus, the ability of a state to penetrate its territories needs to be analytically distinguished from the ability to implement decisions and put policy to work, and the geographic pattern of effective power will vary by objective. ${ }^{12}$

\footnotetext{
${ }^{11}$ These categorical differences create bounded networks, and the ability of the state to exercise control and implement decisions across those patterned social relations may vary (see Tilly 1998).

${ }^{12}$ We are grateful to James Mahon for highlighting this issue, and for this wording.
} 
The contributions to this special issue also help to differentiate between state infrastructural power and public good provision. Mann's original conceptualization of state infrastructural power as the capacity to implement decisions blurs the line between control and provision by including a wide range of policy implementation under the rubric of state infrastructural power. Again, this is an important conceptual distinction to draw. Infrastructurally powerful states may or may not employ their capacities to engage in the creation of public goods. As emphasized by Ziblatt's essay in this collection, a public good is one possible policy output sought by state elites. Likewise, public good provision is shaped by a variety of complex causal factors, among them the motivations of social and political actors and the implementation capabilities of state organizations. Thus, state infrastructural power, at its core, is about the capacity to exercise control. While some public goods, such as security, provide precisely this kind of capacity, others, such as public sewers, might not. ${ }^{13}$

Another important realm where this special issue moves beyond Mann's original work is legitimacy. Even though Mann builds extensively on the Weberian definition of the state, he does not further develop the legitimation of authority in his conceptualization of state infrastructural power. While it is certainly important to conceptually distinguish between state infrastructural power and legitimacy, the precise relationship between the two merits more attention. Supporting beliefs that represent state organizations as bearers of legitimate authority facilitate the actual exercise of state infrastructural power. Analogously, state infrastructural power contributes to the construction of legitimacy, which can be further subdivided into two complementary but analytically distinct forms, identity legitimacy and output legitimacy. Vom Hau's essay emphasizes the former, suggesting that infrastructurally more powerful states may exhibit the organizational machinery and the territorial reach to instil a sense of belonging among their citizenry. Likewise, the everyday presence of state organizations may engender beliefs in the taken-for-granted-ness of state authority (see also Loveman 2005). By contrast, Ziblatt's study of public good provision reflects an output perspective on legitimacy. In this view, infrastructurally powerful states may be better able to provide certain basic services and goods, which in turn enhance the legitimacy of state organizations among the citizenry.

Finally, this special issue also points to the complicated relationship between state infrastructural power and state action. The concept does not capture the goals the coercive, extractive, and regulatory capabilities of state organizations are used for. State infrastructural power has been employed for engendering greater well-being, as well as for committing some of the worst atrocities in human history. ${ }^{14}$ Moreover, there is no assurance that state elites actually exercise the infrastructural power at their disposal, even if the resources and technologies of control are in place.

\footnotetext{
13 This distinction is particularly important when evaluating the new institutional economics and economic history (e.g., Coatsworth 1998; North 1981) and its focus on public good provision as a necessary condition for economic development. By failing to distinguish between public goods and state infrastructural power, this literature ignores major motivations for state development by narrowly focusing on economic growth as the only impetus behind the expansion of state control.

${ }^{14}$ It is not surprising then that Mann's (2005) later work focuses on the role of states in genocide and ethnic cleansing.
} 
Therefore, we must empirically distinguish between the resources constitutive of infrastructural power and the actual use of those resources. It also remains an open question whether the goals that underpin state action shape the effects of state infrastructural power. Lange and Balian's study of the effects of state infrastructural power on civil violence suggests that it does. Their case study of Botswana indicates that when state elites used roads, police officers, and schools with the explicit aim of fostering national development, the containment of civil violence was a more likely outcome. By contrast, the case study of Burma shows that when state infrastructural power was employed with the stated goal of suppressing ethnic minorities, it had conflict-instigating effects. Thus, state infrastructural power is neither good nor bad, yet the goals for which infrastructural power is used may affect how it is deployed and the actual outcomes it generates. ${ }^{15}$

On the whole, the contributions to this special issue illustrate new and valuable ways of putting the conceptual framework of state infrastructural power to work. Covering topics as diverse as democratization, civic violence, race relations, nationalism, and social development, the articles assembled here carefully unpack state infrastructural power for investigating the strength of the state. Jointly, these articles also advance beyond Mann's initial conceptualization to address distinctions between state infrastructural power and public good provision; between spatial and social control; between control and policy implementation; and the relationships between state infrastructural power and the goals of state elites, legitimacy, and democracy. The articles, in their substantive analyses of a wide range of geographic contexts and aspects of social science, thus illuminate the fruitfulness of state infrastructural power for the precise and nuanced study of the state.

Acknowledgements The editors thank the Weatherhead Center for International Affairs at Harvard University and the Faculty Development Fund of Bates College for supporting this project.

\section{References}

Bates RH. Markets and states in tropical Africa. Berkeley: University of California Press; 1981.

Berezin M. Making the fascist self: the political culture of inter-war Italy. Ithaca, NY: Cornell University Press; 1997.

Boudon L. The role of the state in the Colombian peace process. J Lat Am Stud 1996;28:279-97.

Brubaker R. Nationalism reframed: nationhood and the national question in the New Europe. Cambridge, UK: Cambridge University Press; 1996.

Carpenter DP. The forging of bureaucratic autonomy: reputations, networks, and policy innovation in executive agencies, 1862-1928. Princeton: Princeton University Press; 2001.

Centeno MA. Blood and debt: war and the nation state in Latin America. State College, PA: Penn State University Press; 2002

Coatsworth J. Economic and institutional trajectories in nineteenth-century Latin America. In: Coatsworth J, Taylor AM, editors. Latin America and the world economy since 1800. Cambridge: Harvard University Press; 1998. p. 23-54.

Collier D, Levitsky S. Democracy with adjectives: conceptual innovation in comparative research. World Polit 1997;49:430-51.

\footnotetext{
15 The relationship between power and outcomes, which has been a central issue in the philosophical debate about power, is discussed in more detail in Soifer's essay.
} 
Crisis States Research Centre. War, state collapse and reconstruction: phase 2 of the crisis states programme. Working paper no. 1, Crisis States Research Centre, Development Studies Institute (DESTIN), London School of Economics (LSE), London; 2005.

Evans P. Embedded autonomy: states and industrial transformation. Princeton: Princeton University Press; 1995.

Evans P, Rauch JE. Bureaucracy and growth: a cross-national analysis of the effects of "Weberian" state structures on economic growth. Am Sociol Rev 1999;64(5):748-765 (Oct.).

Fearon JD, Laitin D. Ethnicity, insurgency, and civil war. Am Polit Sci Rev 2003;97:75-90.

Fitzgerald D. A nation of emigrants: how Mexico manages its migration. Berkeley, CA: University of California Press; 2008.

Geddes B. Politician's dilemma: building state capacity in Latin America. Berkeley: University of California Press; 1994.

Gellner E. Nations and nationalism. Ithaca, NY: Cornell University Press; 1983.

Goertz G. Social science concepts: a user's guide. Princeton: Princeton University Press; 2005.

Goodwin J. No other way out: states and revolutionary movements, 1945-1991. New York: Cambridge University Press; 2001.

Gorski P. The disciplinary revolution: calvinism and the rise of the state in early modern Europe. Chicago, IL: University of Chicago Press; 2003.

Herbst J. States and power in Africa. Princeton: Princeton University Press; 2000.

Holston J, Caldeira T. Democracy, law, and violence: disjunctions of Brazilian citizenship. In: Agüero F, Stark J, editors. Fault lines of democracy in post-transition Latin America. Coral Gables, Fla.: NorthSouth Center/University of Miami; 1998. p. 263-96.

Huntington SP. Political order in changing societies. New Haven: Yale University Press; 1968.

Inglehart R, Welzel C. Modernization, cultural change, and democracy: the human development sequence. Cambridge, UK: Cambridge University Press; 2005.

Kalyvas S. The logic of violence in civil war. Cambridge, UK: Cambridge University Press; 2006.

Kertzer D, Arel D. Censuses, identity formation, and the struggle for political power. In: Kertzer D, Arial D, editors. Census and identity: the politics of race, ethnicity, and language in national censuses. New York: Cambridge University Press; 2001. p. 1-38.

Kidd A. Manchester: a history. Lancaster: Carnegie; 2006.

Kline H. State building and conflict resolution in Colombia 1986-1994. Tuscaloosa: University of Alabama Press; 1999.

Levitsky S, Murillo MV. Argentine democracy: the politics of institutional weakness. University Park, Pa: Penn State University Press; 2006.

Linz J, Stepan A. Problems of democratic transition and consolidation: Southern Europe, South America, and post-communist Europe. Baltimore: Johns Hopkins University Press; 1996.

Loveman M. The modern state and the primitive accumulation of symbolic power. Am J Sociol 2005;110:1651-83.

Mann M. The autonomous power of the state: its origins, mechanisms and results. Arch Eur Sociol $1984 ; 25: 185-213$.

Mann M. The sources of social power. volume 1: a history of power from the beginning to A.D. 1760. Cambridge, UK: Cambridge University Press; 1986.

Mann M. The sources of social power. volume 2: the rise of classes and nation states 1760-1914. Cambridge, UK: Cambridge University Press; 1993.

Mann M. The dark side of democracy: explaining ethnic cleansing. Cambridge, UK: Cambridge University Press; 2005.

Marshall T. Class, citizenship and social development. Garden City, N. Y.: Doubleday; 1992/1963.

Marx K. The Eighteenth Brumaire of Louis Bonaparte. In: Tucker RC (ed.). The Marx-Engels Reader. New York: Norton; 1978. p. 594-618

Nordlinger EA. On the autonomy of the democratic state. Cambridge: Harvard University Press; 1981.

North D. Structure and change in economic history. New York: Norton; 1981.

O'Donnell G. On the state, democratization and some conceptual problems: a Latin American view with glances at some postcommunist countries. World Dev 1993;21:1355-69.

Putnam R, et al. Making democracy work: civic traditions in modern Italy. Princeton: Princeton University Press; 1993.

Rogers D. The state as a gang: conceptualizing the governmentality of violence in contemporary Nicaragua. Crit Anthropol 2006;26:315-30.

Sartori G. Concept misformation in comparative politics. Am Polit Sci Rev 1970;64:1033-53.

Skocpol T. States and social revolutions: a comparative analysis of France, Russia, and China. Cambridge, UK: Cambridge University Press; 1979. 
Skocpol T. Protecting soldiers and mothers: the political origins of social policy in the United States. Cambridge, MA: Harvard University Press; 1992.

Skowronek S. Building a new American State: the expansion of national administrative capacities, 18771920. New York: Cambridge University Press; 1982.

Snyder R. Scaling down: the subnational comparative method. Stud Comp Int Dev 2001;36(1):93-110 (Spring).

Steinmetz G. Regulating the social: the welfare state and local politics in imperial Germany. Princeton, NJ: Princeton University Press; 1993.

Straus S. The Order of Genocide. Ithaca, NY: Cornell University Press; 2006.

Tilly C. Durable inequality. Berkeley, CA: University of California Press; 1998.

Torpey JC. The invention of the passport: surveillance, citizenship and the state. Cambridge: Cambridge University Press; 2000.

Waldner D. State building and late development. Ithaca: Cornell University Press; 1999.

Weber M. Economy and society: an outline of interpretive sociology. 2 vols. New York: Bedminster; 1922/1968.

Weiss L. Infrastructural power, economic transformation, and globalisation. In: Hall JA, Schroeder R, editors. An anatomy of power: the social theory of Michael Mann. Cambridge: Cambridge University Press; 2006. p. 167-86.

Wimmer A. Nationalist exclusion and ethnic conflict: shadows of modernity. Cambridge, UK: Cambridge University Press; 2002.

Winant H. The world is a Ghetto: race and democracy since World War II. New York: Basic Books; 2001.

Wuthnow R. Communities of discourse. ideology and social structure in the reformation, the enlightenment, and European socialism. Cambridge: Harvard University Press; 1989.

Yashar D. Contesting citizenship in Latin America: the rise of indigenous movements and the postliberal challenge. Cambridge, UK: Cambridge University Press; 2005.

Ziblatt D. Structuring the State. Princeton University Press; 2006

Hillel Soifer is a Lecturer in the Politics Department at Princeton University. He previously served as Assistant Professor of Politics at Bates College. He received his Ph.D. in political science from Harvard University. His main research interests include Latin American political development and state-building and comparative-historical methods. He is currently completing a book manuscript on the origins and long-term persistence of variation in state infrastructural power in Latin America.

Matthias vom Hau is a postdoctoral research fellow in the Brooks World Poverty Institute at the University of Manchester. He received a Ph.D. in sociology from Brown University in 2007. He is currently completing a book manuscript, a comparative-historical analysis of nationalism in twentiethcentury Mexico, Argentina, and Peru. His main research interests are nationalism and ethnicity, health politics, global development, and comparative-historical methods. 